\title{
Research on the Impact of Data Driven on the Cultivation of Innovative Talents in Economics Majors in China
}

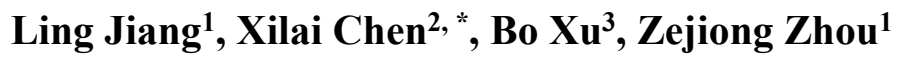 \\ ${ }^{1}$ School of Economics, Anhui University of Finance and Economics, Bengbu, Anhui, China \\ ${ }^{2}$ School of Statistics and Applied Mathematics, Anhui University of Finance and Economics, Bengbu, Anhui, China \\ ${ }^{3}$ Institute of Finance, Anhui University of Finance and Economics, Bengbu, Anhui, China \\ ${ }^{*}$ Corresponding author: Xilai Chen (Email: orangewest@foxmail.com)
}

\begin{abstract}
With the application of Internet big data in the economic field, the requirements for the cultivation of innovative and entrepreneurial talents have been put forward for the current economic universities. Based on the current situation of my country's economic professional talents innovation training under the data-driven background, this article analyzes the impact of data-driven on the training of economic professional innovative talents in my country, and points out the problems in the training of economic professional innovative talents driven by data. And put forward targeted suggestions and opinions.
\end{abstract}

Keywords: Data-driven, Innovative talents, Modern education.

\section{Introduction}

With the application of Internet big data in the economic field, it indicates that our social production mode is undergoing a fundamental change, and has put forward the requirements for the cultivation of innovative and entrepreneurial talents for current economic universities. The National Undergraduate Education Work Conference in the New Era proposed that innovation and entrepreneurship education should be strengthened, and innovation and entrepreneurship education should be integrated into the entire process of economic talent training. Therefore, the cultivation of innovation and entrepreneurship ability of economics college students is a problem that needs to be solved urgently in undergraduate education. The cultivation of economics college students' innovation and entrepreneurship ability relies on practical teaching activities, and practical teaching content is the core of practical teaching. Therefore, in the era of large-scale application of big data, how to strengthen the reform of the practical teaching content system of economics to better meet the needs of college students for training innovation and entrepreneurship is a difficult problem faced by undergraduate colleges and universities in talent training. The key is to school practice teaching reform.

\section{Literature Review}

Many scholars at home and abroad have conducted indepth research on the education and training of innovative talents. Jian $\mathrm{Lu}$ (2018) pointed out that the core ability of innovative talents is creativity, and creativity training is the prerequisite for the cultivation of critical thinking and practical ability. The article clarifies the concept of critical thinking and its impact on innovation and entrepreneurship. The role of education is to analyze the actual practices in innovation and entrepreneurship education. It proposes to promote the development of innovation and entrepreneurship education in terms of strengthening the construction of mentor teams inside and outside the school, improving the material environment for innovation and entrepreneurship, building a sound micro-system environment, and creating an innovative cultural environment [1]. Yuqing Gao (2020) analyzed that the current entrepreneurial education model of economics has many problems in concepts and teaching [2]. These problems are mainly caused by insufficient support from school administrators, weak teaching staff, and insufficient understanding of entrepreneurship education by students. In order to promote the exploration process of the entrepreneurial education model of economics majors, efforts in all aspects are imperative. Liu Gang (2020) emphasized that the emergence of various new business formats based on "Internet + " puts forward brand new requirements for the cultivation of talents in colleges and universities [3]. In the "Internet +" era, colleges and universities' innovation and entrepreneurship education has entered a stage of transformation and development. Based on the analysis of existing problems in innovation and entrepreneurship education, this article focuses on the cultivation of innovative and entrepreneurial thinking in the "Internet + " era, and proposes that universities should focus on school-enterprise collaborative education, curriculum construction, innovation and entrepreneurship network interactive platforms, and training instructor teams, to promote the development of innovation and entrepreneurship education in colleges and universities. Li Chunhua (2020) believes that the professional knowledge structure and unique advantages of economics can provide assistance in broadening the choice of topics, providing preliminary research methods and means, and improving and upgrading the original design for the development of innovation and entrepreneurship activities of college students. For this reason, economics courses need to be reformed, and the theoretical knowledge, computer operations of the courses and the innovation and entrepreneurship practice of college students must be organically integrated, so as to better serve the innovation and entrepreneurship practice of college students and cultivate high-quality talents [4]. Play its due role. Tang Qiming (2021) pointed out that based on the cultivation of college students' innovative and entrepreneurial abilities, a practical teaching 
content system of economics, consisting of "professional basic practice + professional comprehensive practice + innovative and entrepreneurial practice" has been constructed [5]. At the same time, from the three aspects of practical teaching platform construction, practical teaching management mechanism and practical teaching faculty construction, the supporting conditions of the practical teaching content system of the economics major are analyzed to ensure the smooth development of various practical teachings.

Modern education is a social phenomenon that exists widely in the lives of college students, and it is an activity to cultivate social people with a purpose. In order to effectively carry out educational activities for college students, it is necessary to conduct research on college student education, and after long-term accumulation, it becomes a specific research object of pedagogy. The purpose of college student education is to teach college students a wide range of knowledge and content related to life. The substantive subjects or practical courses closely related to the secular life of mankind are the most valuable, and to develop college students' innovative and entrepreneurial abilities. Therefore, university teaching principles and methods should be based on the internal development order of the psychological faculties of university students. Especially the development of modern society, along with the development of modern education practice, has put forward newer and higher requirements for the research on innovation and entrepreneurship education of college students. Educational implementation approaches, methods and forms of innovation and entrepreneurship, as well as their interrelationship issues, education process issues, education systems, education management issues, and various innovation and entrepreneurship education theories and educational practices that reflect Chinese characteristics [6].

Based on the current situation of my country's economic professional innovation training under the background of data-driven, this paper analyzes the degree of data-driven influence on the training of economic professional innovative talents in my country, and points out the problems in the training of economic professional innovative talents driven by data, and put forward targeted suggestions and opinions.

\section{Data-driven Problems in the Training of Innovative Talents in Economics Majors in China}

The new normal of my country's economic development is the main feature of the current stage of development, and realizing the Chinese dream of the great rejuvenation of the Chinese nation will inevitably speed up the construction of an innovative country. For the innovation of financial undergraduates' innovation and entrepreneurship education model, it is necessary to realize the transformation of teaching methods that focus on knowledge transfer to focus on ability and quality training. Innovative and entrepreneurial education mode, comprehensive crossover Undergraduate training mode, to continuously improve the education quality of undergraduates in terms of comprehensive thinking, independent thinking and innovative awareness. It not only needs to master professional theoretical knowledge and professional frontier knowledge, but also needs to cultivate students' practical ability and innovation and entrepreneurship. Competence is not only an important issue facing financial colleges and universities to adapt to the requirements of the new era, but also to create innovation and entrepreneurship education.

Under the background of vigorously advocating innovation and entrepreneurship, to enhance the mutual relationship between student innovation and entrepreneurship education and the optimization of knowledge structure, innovation and entrepreneurship education should be integrated into the practical teaching content system of economics. The following problems are proposed to be solved:

\subsection{The Deviation of Students' Cognition}

Modern college students think that innovation and entrepreneurship are only participating in some business activities or social practices, and even some students think that students with entrepreneurial willingness will care about and participate in innovation and entrepreneurship practice activities, ignoring that innovation and entrepreneurship activities are a further extension of college practical teaching activities. Therefore, the formation of a good sense of general education, the acquisition of knowledge only depends on the curriculum arranged by the school, and the lack of the right to choose and participate in it [7].

\subsection{Lack of Innovation and Entrepreneurship Education Resources in Practical Teaching Content}

In order to tap the students' innovation and entrepreneurship capabilities, most economic colleges and universities use case teaching, scenario simulation teaching and other methods, professional training courses, and the limitations of single format. Using related software to simulate operations in the laboratory, the content of the virtual simulation is somewhat different from the real situation, and it is difficult to improve students' hands-on ability, and it is also difficult to cultivate students' innovation and entrepreneurship capabilities.

\subsection{Out-of-school Innovation and Entrepreneurship Education Is A Mere Formality}

Although off-campus practical teaching can cultivate students' hands-on ability and give students the opportunity to participate in the actual work process of the company, it is just a mere formality. There is no off-campus tutor to guide and train students' innovative. The ability of innovation and entrepreneurship has not been greatly improved.

\section{Countermeasures and Suggestions to Improve the Role of Data-driven in the Cultivation of Innovative Talents in Economics Majors}

\subsection{Construct A Teaching Content System for College Students' Innovation and Entrepreneurship.}

The establishment of an innovative and entrepreneurial education and teaching system is used to guide and standardize scientific research and serve the cultivation of talents. Transforming scientific research resources and advantages into economic talent training resources and advantages is an important support for the high-level 
economic innovation and entrepreneurial talent training system. The goal of the system is to train high-quality professionals in economics with knowledge, strong practical ability, innovative spirit and entrepreneurial awareness, adhere to the spirit of reform and innovation, strengthen student training and improve the construction of the practical teaching system, actively change the concept of development, and establish innovation [8]. Based on the actual situation of students, combined with the current social urgent need for innovation and entrepreneurship, general education is the basis, general education is the foundation, and professional education is the direction to establish a college student innovation and entrepreneurship education system centered on innovation and entrepreneurship education. The foundation is integrated into one innovation and entrepreneurship education. The innovative spirit, entrepreneurial awareness and entrepreneurial ability are integrated into the innovation and entrepreneurship education, the innovative spirit, entrepreneurial awareness and entrepreneurial ability are integrated into this specific education system, and creativity, innovation and entrepreneurship are integrated into each economic category [9].

\subsection{Practice Teaching Content of Innovation and Entrepreneurship Ability.}

The practical teaching content of innovation and entrepreneurship ability is mainly through practical activities such as innovation and entrepreneurship skills competition, innovation and entrepreneurship course training, innovation and entrepreneurship project practice, and enterprise internships, so that students can experience and understand innovation and entrepreneurship knowledge in real work situations, and enable students to have innovation Entrepreneurship ability. Strengthen the construction of practical teaching platform, through the on-campus practical teaching platform, and the on-campus practical teaching platform, let college students truly enter the society and enter the enterprise. In the construction of the off-campus practical teaching platform, actively explore the interests of the enterprise and seek a win-win model so that students can truly participate in various activities of the enterprise. At the same time, in order to ensure the orderly operation of the practical teaching content system of economics, a corresponding practical teaching management mechanism is required.

\subsection{Strengthen the Construction of the Teaching Staff of Practical Teaching.}

The economics professional practice teaching based on the cultivation of college students' innovative and entrepreneurial ability requires teachers to have rich practical experience. Build a project team with practical courses, hire business managers to join the project team, make the company participate in the practical teaching process of economics in the whole process, and establish a long-term communication mechanism with the off-campus practice base enterprise personnel to train the professional practical teaching teachers of economics Practical ability is the core to carry out the construction of practical teaching faculty. Hire business managers to the school to participate in practical teaching activities and give lectures on innovation and entrepreneurship. At the same time, teachers are sent to enterprises to participate in actual work to exercise their practical ability. The third is to strengthen the management of the teaching faculty of economics majors. Guide economics teachers to actively carry out theoretical knowledge and case teaching research in innovation and entrepreneurship education, support teachers to take off-job training in enterprises, and encourage teachers to participate in enterprise innovation and entrepreneurship practice projects [10].

The construction of the practical teaching content system of the economics major is mainly aimed at cultivating the innovation and entrepreneurial ability of college students, integrating the practical teaching resources inside and outside the school to design a series of practical teaching content, so that students have the professional qualities required for the job after graduation, and strengthen employment rate of college students, work ability and entrepreneurial ability. The practical teaching objectives of economics are divided into three progressive levels: basic professional ability, comprehensive professional ability and innovation and entrepreneurship ability. In the basic professional ability stage, through practical teaching, college students can master the basic theories and basic practical ability of economics, and stimulate their interest and willingness to innovate and start a business. At the professional comprehensive ability stage, through practical teaching, students will be proficient in the practical operation skills of economics, and the comprehensive professional ability of college students will be improved. At the stage of innovative and entrepreneurial ability, a variety of practical teaching methods are used to enable college students to have innovative and entrepreneurial thinking. Through participation in innovative and entrepreneurial projects, they can mobilize their interest in entrepreneurship, enhance their entrepreneurial potential, and encourage college students to carry out various innovative and entrepreneurial activities.

In recent years, my country has been moving towards a process of transformation and social employment pressure has increased. Entrepreneurship has gradually become a career choice for college students and graduates. The innovation and entrepreneurship education for college students in my country's universities is to cultivate entrepreneurial talents with creative personality, is the core content of the implementation of quality education and innovation and entrepreneurship base education in universities, and is a forward-looking countermeasure for cultivating high-quality laborers who meet the needs of the new century. Entrepreneurship education for college students and cultivating pioneering talents with entrepreneurial knowledge, pioneering spirit and entrepreneurial ability are new requirements for educational development in the era of knowledge economy. Today, when the employment situation of college students in our country is increasingly severe, it is particularly important to implement entrepreneurial education. Through the implementation of a national-level college student innovation and entrepreneurship training program, my country has promoted the transformation of educational ideology in colleges and universities, reformed the talent training model, strengthened the training of innovation and entrepreneurship, strengthened the innovation ability of college students and the entrepreneurial ability on the basis of innovation, and cultivated adaptation to an innovative country High-level innovative talents needed for construction. Therefore, the innovation and entrepreneurship training program for college students should be included in the talent training program and teaching plan [11]. Participating in the plan, the teaching management department of colleges and 
universities should provide educational support in terms of curriculum construction, student selection, examinations, achievement recognition, credit recognition, and flexible student status management.

\section{Acknowledgement}

This work is supported by the project of Anhui University of Finance and Economics School-level Undergraduate Teaching Quality and Teaching Reform Project in 2021 "Research on the Teaching Mode of Innovation and Entrepreneurship for Economics Majors".

\section{References}

[1] Jian Lu, Xunzhang Zhou, Xiaofang Zhang. Exploration and analysis of innovation and entrepreneurship education based on cultivation of deliberative thinking ability taking the teaching practice of students majoring in economics of Hebei Agricultural University as an example[J].Journal of Agricultural University (Agriculture and Forestry Education Edition), 2018 (06): 21-25.

[2] Yuqing Gao, Lin Wang. Research on the reform of entrepreneurship education model for economics undergraduates $[\mathrm{J}]$. Research and Practice of Innovation and Entrepreneurship Theory, 2020(3): 90-91+111..

[3] Gang Liu, Linsen Zhu. Under the background of "Internet +" college students' innovative and entrepreneurial thinking development education research taking Jilin Institute of Chemical Technology as an example [J]. Think tank era, 2019(12):147-148.

[4] Chunhua $\mathrm{Li}$;Wangchun $\mathrm{Wu}$.Research on the function of "econometrics" course in the practice of college students' innovation and entrepreneurship [J]. Modern trade industry, 2020(5):86-87.
[5] QimingTang, Meijuan Li. Construction of the practical teaching content system of economics specialty based on the cultivation of college students' innovative and entrepreneurial ability[J].Journal of Heilongjiang Teacher Development College, 2021(8):49-51.

[6] Zidan Shan, Jiao Han, Xiaoyan Wang. Researh on the teaching mode of cultivating innovative and entrepreneurial high-end talents from the perspective of "multidimensional integration"[J]. Journal of Heilongjiang Teacher Development College, 2021(12):34-36.

[7] Rui Zhang.Research on "Inter-embedded" Teaching Reform of Digital Media Major in Local Colleges and Universities from the Perspective of Innovation Clusters[J].Higher Education Journal,2021(11):38-41.

[8] Muzi LI.The Academic Innovation Behavior of University Teachers Based on the Perspective of Organizational and Individual Interaction: Taking $\mathrm{G}$ School of Teaching and Research University in the Eastern Coastal Province as an Example[J].Journal of Fujian Education Institute,2021(10):2528

[9] YuanqingChen,JingLi,XiangqiLiu, YanMiao. Exploration of the Teaching Reform of the Basic Platform Course of Economics Based on the Cultivation of Innovative TalentsTaking the Course Teaching of "Western Economics" as an Example[J].Journal of Mudanjiang Institute of Education,2021(10):82-85.

[10] Huishuang He, Leilei Yuan. The construction of the practical teaching evaluation system of economics and trade majors in local colleges and universities under the demand of "double innovation" $[\mathrm{J}]$. Heilongjiang Education (Higher Education Research and Evaluation).2021(8):4-6.

[11] Xiaojian Lin, Xiaoli Shi. A Probe into the Innovative Teaching Mode of "Trinity"-Taking the Course of "Macroeconomics" as an Example [J]. Journal of Jimei University (Educational Science Edition).2021(7):70-75. 